\title{
The Realist Cinema of Lino Brocka
}

Jose Gutierrez III

This essay characterizes the cinema of Lino Brocka as principally realist by (1) underscoring his consistent use of realistic material; (2) highlighting pronouncements by various film scholars on the realist aspects of the Brocka film; (3) identifying realist film tropes distilled from the preceding step; and finally, (4) putting forward the Brocka film's engagement with the life-world as a way to understand the auteur's brand of cinematic realism.

One of the foremost characteristics of the Brocka film is its being based on events that actually happened. This reference to reality, constituted by the Brocka film audience's purview of these events, significantly factors into the spectatorial experience. This has served as the foundation for the auteur's interaction with his public. In the case of Orapronobis (1989), Brocka came up with the film concept when he heard about a sanctuary in the city for village folk who fled from armed groups in their native far-flung province; later, the director developed the story with his scriptwriter, Pete Lacaba, for the film (Maglipon, 1993, p. 141). David (1990) commented on how the film binds documentary events to its narrative that has 'drawn voraciously from known facts-hence sandwiching the presentation between history, on the one hand, and realistic imagery, on the other' (p. 189). A combination of real-life events - a strike at a small factory and a robbery-hostage case-was the basis for Bayan Ko: Kapit sa Patalim/Clutching a Knife (Brocka, 1985) (Hernando, 1993a, p. 18). Besides drawing directly on documentary events, Brocka also portrayed recognizable personalities to create his cinematic 
characters (Hernando, 1993b, p. 48). Gumapang Ka Sa Lusak/Dirty Affair (Brocka, 1990), for example, was replete with such characters. The basis of the costume, make-up and figure movement of the mayor's wife character was the public persona of the former First Lady of the Philippines, Imelda Marcos. To drive the point home, the film even has a scene where the mayor's wife is violently attacked-this was largely seen as an overt parody on an assassination attempt on Imelda Marcos in 1972 (Hernando, 1993b, p. 48).

Aside from public events, Brocka's personal life was also a source of material for his films. Tinimbang Ka Ngunit Kulang/Weighed but Found Wanting (Brocka, 1974) drew on the auteur's childhood memories (Hernando, 1993a, p. 16). On the mad woman character, Kuala, in this film, Brocka recounted, "some years later, she came to me as a symbol of my childhood and I wanted to do a film on her" (Sotto, 1993d, p. 220). Tahan na Empoy, Tahan/Stop Crying Little Boy (Brocka, 1977b), a "showcase of his childhood griefs" (Dalisay, 1993, p. 78), was based on his "turbulent childhood" (Sotto, 1993e, p. 101). Brocka's opening up of his personal life to his actors enriched his connection with them. An actress in Inay/Mother (Brocka, 1977), Laurice Guillen stated how this facilitated her performance: "the film was based on his life and I already understood the material very well because he had told me everything about his family"'(Torre, 1993, p. 92). Known as an actor's director (Hernando, 1993a, p. 15), Brocka would "coax the authenticity of emotion" (Sotto, 1993e, p. 115) from his actors. Gina Alajar, who played the lead actress in Orapronobis (Brocka, 1989), relayed, "Many of the elements of the story came from his personal experiencesthe scene where I left the courtroom, when I was abducted, he himself had seen someone being abducted-so he was able to make the situation very real to me" (Torre, 1993, p. 90). Brocka believed that the characters in Insiang (Brocka, 1976) were "real" since they were based on actual referents in the slums; further, the director commented that other films that show the slums use "characters adapted from the komiks" (Sotto, 1993a, p. 228) which were popular during the era. Insiang, according to Brocka, manifests his "preference to show people who fight in order to survive with dignity in the most abject of conditions rather than show the merrymaking of public relations agents" (Sotto, 1993a, p. 227) that serve the propaganda of the Marcos regime.

The realist aspect of Brocka films has been noted by film critics and scholars. Hernando (1983) remarked that Maynila sa mga Kuko ng Liwanag/ Manila in the Claws of Light (Brocka, 1975) is "the most honest and realistic story of the cruel city” (p. 212). Even Brocka's early film, Santiago (1970), while executing the demands of the war film genre, had "sufficient serious 
content and realistic characterizations to impress critics" (Hernando, 1993a, p. 14). Throughout his career, Brocka was distinguished for making his "characters more realistic" (Hernando, 1993a, p. 14) -in the auteur's words, "I was introducing the Filipino audience not to caricatures but to characters, a character study" (Garcia, 1993, p. 217). It was also important for Brocka to be realistic in terms of the shooting location. In shooting Lunes, Martes, Miyerkules, Huwebes, Biyernes, Sabado, Linggo/Monday, Tuesday, Wednesday, Thursday, Friday, Saturday, Sunday (1976), when his crew offered a more convenient alternative to shoot in Manila instead of a faraway city in the north, Brocka insisted otherwise, as he believed they would not be able to capture the "ambience and reality of the "Sin City" if they merely used production design to simulate the original setting (Hernando, 1993b, p. 39); at that point, the crew then understood that 'the director wanted the "truth" (p. 45).

Another factor that influenced the realist cinema of Lino Brocka was his advocacy for developing the Filipino audience; in particular, the popular auteur deployed his realist aesthetics to address the prevailing escapism in mainstream cinema. Brocka observed that although more and more people were seeing films than ever before, they were "watching movies that are as far removed from their lives as possible" (Aufderheide, 1987, p. 75). Brocka had always been conscious of his realist approach: "My first film, Wanted: Perfect Mother (Brocka, 1970) was directed at a time when Philippine cinema was full of clichés. I decided to make the characters more real" (Sotto, 1993a, p. 229). The Brocka film goes against the grain of the escapist cinema in which "dreams are shown on the screen rather than analyses of the human condition" (Sotto, 1993a, p. 229). In his second film, Santiago (1970), Brocka was marked for his sense of realism in "the most improbable of local films, an FPJ movie" (Parel, 2010, p. 238). The founding in 1976 of the Manunuri ng Pelikulang Pilipino (MPP) [Filipino Film Critics], the only critics group in the Philippines at the time, propelled the realist and auteurist Brocka film to jump-start the "Second Golden Age" (Tolentino, 2012, p. 121) of Philippine cinema. The MPP established the Gawad Urian film awards, the criteria of which "preferred cinema that deals with Philippine social realities over those which are merely skillfully or artfully made" (Lumbera, 1984, p. 208). It signaled the emergence in local films of a "new sensibility which consists principally in a deep respect for the audience and manifests itself in an analytical exploration of character and realistic awareness of social realities" (Lumbera, 1997, p. 116). Brocka infused his films with a "sense of realism" and "projected the creeping poverty that is eating up the moral fabric of his characters" (Hernando, 1993b, p. 41). The director enunciated his films on the same wavelength as the film critics-Clutching a Knife 
(Brocka, 1985) in terms of its "unrelieved sense of social repression and the tragedy at its end" (Guillermo, 2001, p. 211) and Bona (1980) as a "case study" of a certain social phenomenon observable in contemporary social reality (Sotto, 2001, p. 272).

By being principally realist, the Brocka film has been critically remarked as having the ability to "lead the viewer to draw certain disturbing conclusions about the society in general" (Francia, 1987, p. 213). On the auteur's signature "social drama films" that were set in particular locales such as the slum area, small town or factory (Tolentino, 1996, p. 374), Brocka declared his preoccupation "with truths for the individual and with exposing a town to its festering corruption" (Sotto, 1993d, p. 222). Brocka films tackle various evils in government and the police-military, from the "suppression of the ugly truth practiced by powerful politicians to the summary execution by the authorities or private armies of individuals who are a threat to the status quo" (Hernando, 1993b, p. 40). This characteristic treatment of socially relevant subject matters has been understood by critics, scholars and even ordinary viewers as the activist-filmmaker's projections of "a microcosm of the nation's political dynamics" (Tolentino, 2003, p. 77) and "turmoil during the Marcos dictatorship and the succeeding Aquino administration era" (1996, p. 374). The Brocka film is designed as a spectatorial experience that provides insight on the individual's place in society; this introspection fosters ruminations on possible actions by the collective. By the end of the distinctive Brocka film, however, the narrative goes back to the individual who, though not necessarily deciding to pursue the path of mass action, ends up with critical insight into his or her place in society. Brocka's description of Julio Madiaga, the protagonist in Manila in the Claws of Light (Brocka, 1975) is indicative of this: "He begins as an observer but ends up as a participant. Once he understands the situation, he makes a move, no matter how hopeless it is ... The ending is the beginning. He is now a man" (Sotto, 1993b, p. 232). When he was asked to explain why this character was a symbol of the Filipino people, Brocka responded: "You can hit him, kick him and he will smile back at you. He will smile and smile again. But if you take out all his hopes, watch out because he will kill you" (Sotto, 1993c, p. 226).

The realist Brocka film-the form and content of which are shaped by the confluence of historical, technological, aesthetic and sociological factors during and a few years after the Era of Martial Law_can be characterized by the following tropes: (a) "milieu formation" (David, 1990, p. 188); (b) "sweating physicality" (Sotto, 1993e, p. 102); and (c) "characters in the background" (Hernando, 1993b, p. 46). 
With Miguelito: Ang Batang Rebelde/Miguelito: Rebel Boy (Brocka, 1985) and Insiang (Brocka, 1976) as examples, David (1990) identified "milieu formation" (p. 188) as a salient characteristic of the Brocka film. On the latter film, Brocka expounded, "It's a fight between mother and daughter. I like dramas which are situated in a social milieu" (Sotto, 1993a, p. 227). Laurice Guillen, a Filipino actress who eventually became a noted Philippine director, avowed that part of Brocka's gift was "that the milieu of his audience was also his own milieu (he came from them)" (Torre, 1993, p. 94). In Manila in the Claws of Light (Brocka, 1975) and in most of his other works, Brocka manifested his "predilection for cinéma verité by incorporating documentary footage and remains faithful to its dictum of minimizing technical manipulation" (David, 2010, p. 216). Tagged by David (2011) as "Brocka's neorealist masterwork" (p. 88), this film is characterized by its unglamourized makeup, low-keyed acting, careful physical typing of characters, and, "without being shrill about its message, eloquently addresses us about economic conditions that grind down people who have only innocence and goodwill as their armour" (Lumbera, 1997, p. 116). Clutching a Knife (Brocka, 1985), David (1990) observed, optimized "reality as raw material, and at one point the action was in fact transposed to an ongoing protest march" (p. 189). Brocka's final film, Sa Kabila ng Lahat/ In Spite of Everything (1991), contains a "relatively seamless integration of documentary and fictional footage, facilitated by the reflexive device of setting its characters in the profession of mass media documentarists" (David, 2010, p. 216). The Brocka film was closely associated with the social realist genre during the 1970s to mid-1980s, "when Filipino film directors and scriptwriters began using the term 'milieu movie" (David, 2011, p. 88) that enabled the 'depiction of interacting social agents' (p. 90) that configure a "social formation-in fact, a social character-within the diegesis of the film text" (p. 89). Manila in the Claws of Light (Brocka, 1975) for instance, which has been taken as a realist film, is read as a "derailing of the Marcosian project of image- and nation-building" (Tolentino, 2012, p. 124) while "it looks with sympathy on the common man and the human condition" (Hernando, 1993a, p. 17). This "pioneer urban realist film" (Campos, 2011, p. 5) tends to "highlight marginal characters and social problems" (p. 6). It was in this film that his "realist effect" was first realized, one of its foundations being Brocka's "inclination to choose subjects (i.e., main characters) and subject matters that resonate with the "real" or "everyday" way of life of slumdwellers" (Campos, 2011, p. 5). The milieu is viewed from the perspective of a worker, who is part of the migration of large numbers of people from the countryside to Manila and the associated growth of a populace referred to locally as the "urban poor" (Vick, 2007, p. 230). These 
were the people who make up Manila's cheap labor force and inhabit the city's shanty towns and squatter settlements. They embodied up to one third of Metro Manila's population of around eight million people at that time and have formed a "major element within the developing Philippine proletariat" (Pinches, 1985, p. 152).

The Brocka film has also been noted for its "sweating physicality" (Sotto, 1993e, p. 102) complemented by sweltering human emotions "offering a sharp contrast to the cerebral hemorrhage of the pedantic" (p. 102). The physical reality of the shots in Brocka's urban realist films clashes with the idealistic, sterile and airtight imaging of the New Society, which was imagined by the Marcos regime as the "wellspring of the modern Philippine nation" (Tolentino, 2010, p. 98), one in which the Communist and "immoral" citizen was deemed to be subversive (2012, p. 117). New Society also sought to create a new kind of "disciplined" metropolitan citizen through martial rule, as its slogan, "sa ikauunlad ng bayan, disiplina ang kailangan" [for national development, discipline will be essential] (p. 117) makes clear.

Another salient characteristic of the Brocka film is its cinematic rendering of the "characters in the background" (Hernando, 1993b, p. 46); with this as springboard, the director then examined "how personal relationships and how the environment and the other bigger forces shape the destiny of his characters" (p. 48). Brocka's forte was in portraying the "little people," the "generally politically unaware people who are too wrapped up in their middling existence which revolves around love, sex, procreation and a little money to spend at the Luneta [Park]" (Parel, 2010, p. 236). This cinematic engagement with their bodies-fluidly shifting between the individual and collective and deeply enmeshed in the sweating physicality of the milieucuts across Brocka's body of work. These characters in the background serve as the embodiments of emotion, worldview and ultimately, insight into the life-world of the people who were traumatized by violence during the Marcos regime. These were the people who had to hear about the disappearance of Marcos's former ally, Primitivo Mijares, and the brutal murder of his son: "The mutilation of the body was typical of incidents, where, to extract information from an uncooperative prisoner, one member of the family was grotesquely tortured in front of another" (Seagrave, 1988, p. 274). In addition, they are the same people who physically experienced the prevailing violence, and the fear and paranoia that it elicited were powerful forces that contributed to the perpetuation of the Marcos dictatorship: "The impression of power and omniscience was exaggerated by showmanship and grotesque extremes of cruelty" (p. 421).

The distinctive tropes of the Brocka film - namely, (a) "milieu formation" (David, 1990, p. 188); (b) "sweating physicality" (Sotto, 1993e, p. 102); and (c) 
"characters in the background" (Hernando, 1993b, p. 46)—can be employed to understand how the Brocka film interacts with its public through the medium's engagement with the life-world. The power of the principally realist Brocka film lies beyond its being chiefly based on realistic material or its ability to allude to social issues on an ideological level. What the Brocka film has mastered is its resonance with experience-what we discover in natural cognition as the "world," that is, the totality of individual objects that could possibly be experienced, is precisely what Husserl, founder of phenomenology, calls "reality" (Russell, 2006, p. 22). What Husserl called "everyday lived experience" is characterized by its being caught up in the life-world (Russell, 2006, p. 184), which is defined as "the world given to us most immediately: the world-horizon in which we live without making it thematic as a world" (Husserl, 1970, p. 379). The life-world, or Lebenswelt, is "the surrounding ever-changing world of our everyday experience and perception" (Aitken, 2016, p. 15). The realist film tropes distilled from Brocka films serve as fulcrums between cinema and experience. In the Brocka film, the drama is enmeshed with the everyday lived experience of the people, involving, for example the sweating physicality experienced by the working class. It is distinctive of the Brocka film to fluidly map out the activities in the milieu, whether it be in the slums, small town, construction site, market, factory, television studio, convent, the street, etc., and tap into its life-world through figure movement and organic interjections of the characters in the background, which are foregrounded in eclectic, oftentimes poignant, cinematic moments. Brocka used burning human emotions within the familiar but constantly innovating melodramatic style and lived experience-as rendered by tropes such as milieu formation, sweating physicality, characters in the background-to cinematically engage the spectators to contemplate the everyday, not ideologically, but physically. On this plane, they go "back to the things themselves" as Husserl would put it, to allow the phenomena to dictate the terms of their own explication (Russell, 2006, p. 18). This leads the active spectator to gain renewed insight on everyday lived experience, his or her place within the life-world, and resultant possibilities for action. This accounts for the real power of this auteur's body of work. 


\section{References}

Aitken, I. (2016). Introduction. In I. Aitken (Ed.), The major realist film theorists: A critical anthology (pp. 1-40). Edinburgh: Edinburgh University Press.

Aufderheide, P. (1987, Nov). Oriental insurgents. Film comment, 23(6), pp. 73-80.

Campos, P. F. (2011). The intersection of Philippine and global film cultures in the new urban realist film. Plaridel: A Philippine journal of communication, media, and society, 8(1),1-20.

Dalisay, J. J. (1993). From Gingoog to Greenhills: Lino and his writers. In M. A. Hernando (Ed.) (Ed.), Lino Brocka: The artist and his times (pp. 74-85). Manila: Cultural Center of the Philippines.

David, J. (1990, January 10). After the revolution. National midweek, 28-29.

David, J. (2010). The 'new' cinema in retrospect. In N. Tiongson (Ed.), The Urian anthology 1990-1999 (pp. 58-83). Manila: University of the Philippines Press.

David, J. (2011). Primates in paradise: Critical possibilities of the milieu movie. Kritika kultura: A refereed electronic journal of literary/cultural and language studies, 17, 70-104.

Francia, L. (1987). Philippine cinema: The struggle against repression. In J. D. Downing,(Ed.), Film \& politics in the Third World (pp. 209-218). New York: Autonomedia, Inc.

Garcia, F. (1993). Lino Brocka: Direktor para sa mga Pilipino. In M. A. Hernando (Ed.)(Ed.), Lino Brocka: The artist and his times. Manila: Cultural Center of the Philippines.

Guillermo, A. (2001). Bayan Ko Kapit Sa Patalim: Desperate measures. In N. Tiongson (Ed.), The Urian anthology, 1980-1989: Film essays and reviews by the Manunuri $\mathrm{Ng}$ Pelikulang Pilipino with a Filmography of Philippine Movies, 1980-1989 (pp. 211-213). Manila: A.P. Tuviera.

Hernando, M. A. (1983). 'Maynila': Brocka's best, a review of 'Maynila sa mga Kuko ng Liwanag'. In N. Tiongson (Ed.), The Urian anthology, 1970-1979: Selected essays on tradition and innovation in the Filipino cinema of the 1970s by the Manunuring Pelikulang Pilipino (pp. 210-213). Manila: M.L. Morato.

Hernando, M. A. (1993a). Biography: Lino Brocka. In M. A. Hernando (Ed.), Lino Brocka: The artist and his times (pp. 7-20). Manila: Cultural Center of the Philippines.

Hernando, M. A. (1993b). Lino Brocka: Director in control - blending popular entertainment, realism and social comment. In M. A. Hernando (Ed.), Lino Brocka: The artist and his times (pp. 38-48). Manila: Cultural Center of the Philippines.

Husserl, E. (1970). The crisis of European science and trancendental phenomenology. Evanston, IL: Illinois University Press.

Lumbera, B. (1984). Problems in Philippine film history. In B. Lumbera (Ed.), Revaluation: Essays on Philippine literature, cinema and popular culture (pp. 193-212). Quezon City: Index.

Lumbera, B. (1997). Maynila sa mga Kuko ng Liwanag, a review. In B. Lumbera (Ed.), Revaluation 1997: Essays on Philippine literature, cinema and popular culture (pp. 200-203). Manila: University of Santo Tomas Publishing House.

Maglipon, J. Q. (1993). The Brocka battles. In M. A. Hernando (Ed.), Lino Brocka: The artist and his times (pp. 118-154). Manila: Cultural Center of the Philippines.

Parel, T. (2010). The passions of Lino Brocka. In N. G. Tiongson (Ed.), The URIAN anthology: 1990-1999 (pp. 236-243). Quezon City: University of the Philippines Press.

Pinches, M. (1985). The 'urban poor'. In R. May, \& F. Nemenzo (Eds.), The Philippines after Marcos (pp. 15263). London and Sydney: Croom Helm. 
Russell, M. (2006). Husserl: A guide for the perplexed. London and New York: Continuum.

Seagrave, S. (1988). The Marcos dynasty. New York: Fawcett Columbine.

Sotto, A. (1993a). Interview with Lino Brocka on "Insiang". In M. A. Hernando (Ed.), Lino Brocka: The artist and his times (pp. 227-30). Manila: Cultural Center of the Philippines.

Sotto, A. (1993b). Interview with Lino Brocka on "Jaguar". In M. A. Hernando (Ed.), Lino Brocka: The artist and his times (pp. 231-33). Manila: Cultural Center of the Philippines.

Sotto, A. (1993c). Interview with Lino Brocka on "Maynila sa mga Kuko ng Liwanag". In M. A. Hernando (Ed.), Lino Brocka: The artist and his times (pp. 223-226). Manila: Cultural Center of the Philippines.

Sotto, A. (1993d). Interview with Lino Brocka on "Tinimbang Ka Nguni't Kulang". In M. A. Hernando (Ed.), Lino Brocka: The artist and his times (pp. 220-22). Manila: Cultural Center of the Philippines.

Sotto, A. (1993e). Lino Brocka - The international director. In M. A. Hernando (Ed.), Lino Brocka: The artist and his times (pp. 101-117). Manila: Cultural Center of the Philippines.

Sotto, A. (2001). Interview with Lino Brocka on Bona. In N. Tiongson (Ed.), The Urian anthology, 19801989: Film essays and reviews by the Manunuri $\mathrm{Ng}$ Pelikulang Pilipino with a filmography of Philippine movies, 1980-1989 (pp. 272-5). Manila: A.P. Tuviera.

Tolentino, R. B. (1996). 'Inangbayan' in Lino Brocka's Bayan Ko: Kapit sa Patalim (1985) and Orapronobis (1989). Screen, 37(4), 368-88.

Tolentino, R. B. (2003). Postnational family/postfamilial nation: Family, small town and nation talk in Marcos and Brocka. Inter-Asia Cultural Studies, 4(1), 77-92.

Tolentino, R. B. (2010). Vaginal economy: Cinema and globalization in the post-Marcos post-Brocka Era. Humanities Diliman, 95-114.

Tolentino, R. B. (2012). Marcos, Brocka, Bernal, city films, and the contestation for imagery of nation. Kritika Kultura, 115-38.

Torre, N. (1993). Lino Brocka and his actors: A question of trust. In M. A. Hernando (Ed.), Lino Brocka: The artist and his times (pp. 86-100). Manila: Cultural Center of the Philippines.

Vick, T. (2007). Asian cinema: A field guide. New York: HarperCollins Publishers, Inc.

\section{Filmography}

Brocka, L. (Director). (1970). Santiago. Philippines: Lea Productions.

Brocka, L. (Director). (1970). Wanted: Perfect Mother. Philippines: Lea Productions.

Brocka, L. (Director). (1974). Tinimbang Ka Ngunit Kulang/Weighed but Found Wanting. Philippines: CineManila; Mever Films.

Brocka, L. (Director). (1975). Maynila sa mga Kuko ng Liwanag/Manila in the Claws of Light. Philippines: Cinema Artists.

Brocka, L. (Director). (1976). Insiang. Philippines: CineManila.

Brocka, L. (Director). (1976). Lunes, Martes, Miyerkules, Huwebes, Biyernes, Sabado, Linggo/Monday, Tuesday, Wednesday, Thursday, Friday, Saturday, Sunday. Philippines: Mever Films.

Brocka, L. (Director). (1977). Inay/Mother. Philippines: Lotus Films.

Brocka, L. (Director). (1977). Tahan na Empoy, Tahan/Stop Crying Little Boy. Philippines: Lotus Films.

Brocka, L. (Director). (1980). Bona. Philippines: NV Productions.

Brocka, L. (Director). (1985). Bayan Ko: Kapit sa Patalim/Clutching a Knife. Philippines: Malay Films; Stephan Films

Brocka, L. (Director). (1985). Miguelito: Ang Batang Rebelde/Miguelito: Rebel Boy. Philippines: D'Wonder Films.

Brocka, L. (Director). (1989). Orapronobis. Philippines/USA: Cannon Films.

Brocka, L. (Director). (1990). Gumapang Ka Sa Lusak/Dirty Affair. Philippines: Viva Films. 
Brocka, L. (Director). (1991). Sa Kabila ng Lahat/In Spite of Everything. Philippines: Viva Films.

JOSE GUTIERREZ III is an assistant professor at the University of the Philippines Film Institute (UPFI), a filmmaker, and a PhD candidate (Film Studies) at the Hong Kong Baptist University (HKBU). He holds a Master of Arts in Media Studies (Film) degree and a Bachelor of Arts in Psychology degree from the University of the Philippines-Diliman. His portfolio as an experimental-documentary filmmaker is presented in his official website: www.JoniGutierrez.com. The research that led to the current article was supported by the University of the Philippines through the PhD Incentive Award given to the author. (Corresponding author: jcgutierrez3@up.edu.ph) 